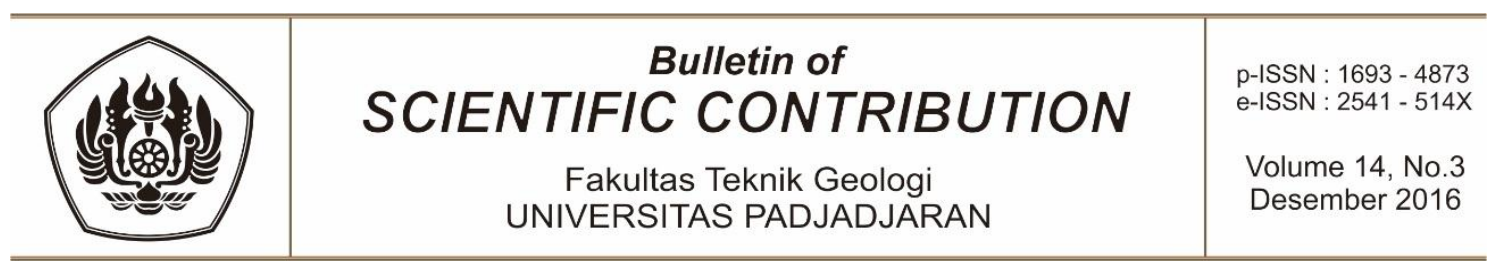

\title{
Aktivitas Tanah Lempung Pada Formasi Bojongmanik Terhadap Kestabilan Lereng di Daerah Cikopomayak, Kabupaten Bogor, Provinsi Jawa Barat
}

\author{
Alifahmi; R. Irvan Sophian; Dicky Muslim \\ Fakultas Teknik Geologi, Universitas Padjajaran \\ J. Raya Bandung-Sumedang KM 21, Jatinangor, Sumedang, Jawa Barat, 43563
}

\begin{abstract}
ABSTRAK
Formasi Bojongmanik merupakan formasi yang salah satu material penyusunya merupakan batulempung. Berdasarkan pemetaan geologi teknik yang telah dilakukan daerah penelitian memiliki jenis tanah lempung berplastisitas tinggi $(\mathrm{CH})$ dan lanau berplastisitas tinggi $(\mathrm{MH})$ menurut klasifikasi USCS (Unified Soil Clasification System). Kondisi tanah dengan plastisitas tinggi merupakan kondisi dimana tanah dapat merubah bentuk dengan mudah akibat adanya pengaruh kenaikan kandungan air. Aktivitas mineral lempung merupakan salah satu faktor yang mengatur kestabilan lereng, dimana tanah lempung memiliki sifat dapat menyusut dan mengembang bergantung pada kadar air. Berdasarkan nilai aktivitas lempung yang diperoleh pada daerah penelitian dengan membandingkan nilai indeks plastisitas terhadap presentase kandungan lempung didapat pada lapisan bagian atas tanah (kedalaman $0.5-1 \mathrm{~m}$ ) memiliki nilai aktivitas lempung yang tinggi ( $>125$ ) dengan jenis lempung Montmorilonite dan lapisan tanah bagian bawah (kedalaman $2-4 \mathrm{~m}$ ) memiliki nilai aktivitas lempung rendah $(<0.75)$ dengan jenis mineral kaolinite hingga aktivitas lempung normal (0.75-1.25) dengan jenis mineral illite. Meskipun nilai safety factor pada daerah penelitian lebih besar dari angka stabil yang dinyatakan oleh Bowles, yaitu diatas 1.25 , bahaya longsor masih memungkinkan terjadi pada saat tanah berada dalam kondisi basah, hal ini dikarenakan kandungan air dalam lempung meningkat memicu kenaikan aktivitas lempung sehingga menyebabkan kenaikan volume pada lempung. Pada peristiwa tersebut kondisi lereng akan mengalami ketidak stabilan sehingga pergerakan massa tanah terjadi untuk mencapai titik setimbang lereng tersebut.
\end{abstract}

Kata kunci: kestabilan lereng, safety factor, mineral lempung, longsor

\section{PENDAHULUAN}

\section{Latar Belakang}

Formasi Bojongmanik merupakan salah satu formasi yang yang disusun oleh material batulempung. Berdasarkan peta geologi teknik lembar serang, daerah penelitian didominasi oleh satuan tanah residual dari pelapukan batulempung. Ciri khas yang dimiliki oleh mineral lempung adalah kemampuan mengembang atau disebut ekspansif bertgantung terhadap kadar air. Tetapi sifat lempung yang ekspansif ini sewaktu-waktu dapat mengganggu kestabilan lereng, dimana saat tanah lempung menyerap air dengan maksimal sehingga volume tanah lempung mengalami peningkatan yang mengakibatkan kondisi lereng tidak stabil, hal ini dapat menyebabkan momen pemicu longsor memiliki gaya yang lebih besar daripada momen penahan longsor, sehingga dalam prinsip kestabilan lereng apabila peristiwa tersebut berlangsung akan terjadi longsor.

\section{Lokasi Daerah Penelitian}

Daerah penelitian terletak di desa Cikopomayak, Kecamatan jasinga, Kabupaten Bogor, Provinsi Jawa Barat. Berdasarkan letak geografis daerah penelitian berada pada 106026'25.6" BT hingga $106028^{\prime} 45.4^{\prime \prime}$ BT dan -6027'54.2" LS hingga 6026 '10.8" LS. Kawasan ini didominasi oleh perkebunan warga terutama Perkebunan Karet, hutan jati ambon, jati londo, hutan albasiah, dan tak jarang ditemui perkebunan buah dan sayur produktif seperti singkong, pepaya, dan rambutan.

\section{Geologi Daerah Penelitian}

Berdasarkan peta geologi regional lembar Serang menurut Rusmana (1991), daerah penelitian terdiri dari formasi Bojongmanik, Intrusi andesit, dan endapan aluvium. Dimana Formasi Bojongmanik merupakan Formasi tertua pada daerah penelitian dan endapan aluvium merupakan produk batuan termuda pada daerah penelitian. Formasi Bojongmanik (Tmb) terdiri atas batupasir, tufa batuapung, napal dengan moluska, 
batugamping, batulempung dengan lempung bitumen dan sisipan lignit dan sisa damar. Tebal satuan ini diperkirakan mencapai 550 meter. Fosil dalam batulempung adalah plankton yang menunjukkan umur Miosen Tengah. Satuan ini dikorelasikan dengan formasi Subang di daerah Subang.

Geologi Teknik Daerah Penelitian

Kondisi geologi teknik regional daerah penelitian menurut Sudrajat \& Sudibjo (1992), litologi dan karakteristik keteknikan pada daerah penelitian merupakan Lempung dan lempung pasiran $(\mathrm{R}(\mathrm{c})(\mathrm{cs})$ ), dimana terdiri dari tanah residu hasil pelapukan dari batulempung dan napal, tebal antara 1-3 meter berwarna coklat hingga coklat kehitaman, stempat mengandung pecahanpecahan batulempung dan napal, plastisitas dan kelulusan rendah, konsistensi lunak, daya dukung yang diijinkan rendah hingga sedang, penggalian mudah hingga agak sukar bila menggunakan peralatan non mekanik. kedalaman muka air tanah bebas dalam, pada beberapa tempat tidak dijumpai airtanah bebas, di daerah ini setempat setempat dijumpai gerakan tanah.

\section{METODOLOGI}

\section{Pemetaan Geologi Teknik}

Dearman (1991, dalam Zakaria 2010) mengklasifikasikan pemetaan geologi teknik berdasarkan skala peta dan tujuan dari pemnggunaan peta sebagai berikut:

- Engineering type, peta jenis ini berskala lebih besar dari 1:5.000. Informasi yang didapat sangat detail. Jenis peta ini identik dengan Peta Singkapan Detail berskala besar yang memuat sifat fisik- mekanik material, derajat pelapukan, konsistensi dan lain-lain.

- Lithologycal type, peta berskala 1:5.000 sampai 1:10.000 memuat detail geologi yang menonjol. Batas pengujian insitu seperti uji geofisik, pemboran dan sampling lainnya termasuk uji laboratorium secara sistematis dapat dicantumkan.

- Engineering formation, pada skala 1:10.000 sampai $1: 200.000$ lebih kecil. Memuat daerah pemetaa dengan analisis fasies. Satuan peta dicirikan dengan penyelidikan petrografi, geofisik, pemboran, sampling dan sifat indeks. Metoda pemetaan dapat melaui remote sensing (foto udara maupun citra satelit).

- Engineering groups, peta berskala 1:200.000 atau lebih kecil sehingga hanya sifat keteknikan geologi saja yang dipetakan. Metoda pembatasan satuan peta untuk peta geologi dengan pemetaan dapat melalui inderaja (citra satelit).
Pemetaan geologi teknik dalam penelitian in menggunakan peta berdasarkan skala Dearman (1991), yaitu mencakup Lithologycal type, yaitu peta berskala 1:5.000 sampai 1:10.000 memuat detail geologi yang dominan. Batas pengujian insitu seperti uji geofisik, pemboran dan sampling lainnya termasuk uji laboratorium secara sistematis termasuk dalam pemetaan pada skala ini.

Pengambilan sampel pada daerah penelitian terdiri dilakukan dengan menggunakan tiga metode, yakni metode test pit (untuk pengambilan sampel tanah kedalaman $0.5-1$ meter), handauger (untuk pengambilan sampel tanah kedalaman 2-4 meter), dan pemboran sedalam 20 meter untuk mengetahui variasi material secara vertikal.

Untuk penamaan tanah pada daerah penelitian menggunakan sistem penamaan USCS (Unified Soil Classification System) berdasarkan kenampakan fisik tanah dilapangan. Sistem klasifikasi ini dikembangkan oleh Casagrande selama perang dunia kedua, pada tahun 1969 sistem penamaan ini diadopsi oleh ASTM (Hunt, 2007).

Tabel 1. Klasifikasi USCS

\begin{tabular}{|c|c|}
\hline Simbol & Pengertian \\
\hline G & kerikil (gravel) \\
\hline $\mathbf{S}$ & pasir (sand) \\
\hline C & lempung (clay) \\
\hline $\mathbf{M}$ & Ianau (silt) \\
\hline 0 & $\begin{array}{l}\text { lanau atau lempung organik } \\
\text { (organic silt or clay) }\end{array}$ \\
\hline Pt & $\begin{array}{l}\text { tanah gambut dan tanah organik } \\
\text { tinggi (peat and highly organic } \\
\text { clay) }\end{array}$ \\
\hline $\mathbf{W}$ & gradasi baik (well graded) \\
\hline $\mathbf{P}$ & gradasi buruk (poor graded) \\
\hline H & plastisitas tinggi (high plasticity) \\
\hline $\mathbf{L}$ & $\begin{array}{lll}\text { plastisitas } & \text { rendah } & \text { (low } \\
\text { plasticity) } & & \end{array}$ \\
\hline
\end{tabular}

\section{Pengujian Sifat Fisik dan Sifat Mekanik}

Pengujian sifat fisik dan sifat mekanik dilakukan untuk mendapatkan variabel yang diperlukan dalam tahap pengolahan data. 
Untuk tahap analisis kestabilan lereng variabel yang diperlukan diantaranya adalah bobot isi, kohesi, dan sudut geser dalam. Sedangkan untuk tahap analisis angka aktivitas lempung variabel yang diperlukan adalah indeks plastisitas dan kandungan mineral lempung.

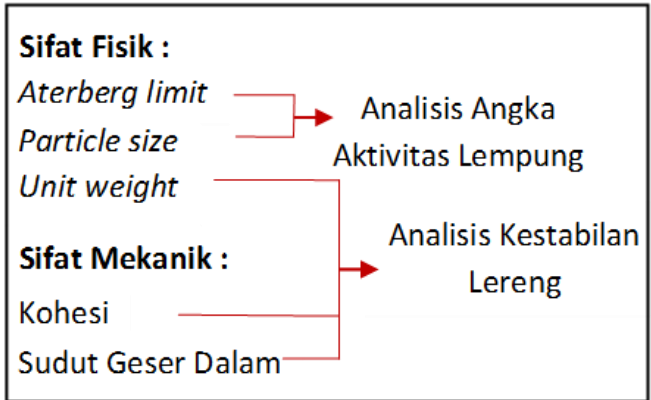

Gambar 1. Uji laboratorium yang diperlukan dalam tahap analisis penelitian

\section{Analisis Kestabilan Lereng}

Setelah mendapatkan data dan mempelajari parameter yang berpengaruh terhadap kestabilan lereng baik yang diperoleh di lapangan, laboratorium, maupun studio kemudian dapat dilakukan analisis kestabilan lereng dengan bantuan software SLIDE untuk mendapatkan nilai FS. Parameter yang diperlukan dalam menganalisis kestabilan lereng ini diantaranya :

\section{Geometri Lereng}

Dalam analisis kestabilan lereng ini geometri lereng diperoleh berdasarkan kontur topografi dengan skala peta 1:8000 dan interval kontur $4 \mathrm{~m}$. Parameter geometri lereng yang diperlukan adalah tinggi lereng, panjang lereng, dan sudut lereng alami yang terbentuk. Geometri lereng diperoleh berdasarkan penampang yang dibuat menggunakan software Global Mapper berdasarkan kontur topografi.

\section{Sifat Fisik \& Mekanik Material}

Sifat fisik dan mekanik merupakan salah satu faktor yang berpengaruh terhadap kestabilan lereng baik material tanah maupun batuan. Sifat fisik dan mekanik suatu material dapat diketahui setelah melakukan uji laboratorium. Dalam simulasi kestabilan lereng menggunakan SLIDE nilai sifat fisik dan mekanik yang diperlukan adalah :

a. Bobot isi (Unit weight)

b. Kohesi

c. Sudut geser dalam

Faktor keamanan secara umum dapat didefinisikan sebagai perbandingan antara gaya penahan longsor terhadap gaya penyebab longsor pada suatu lereng (Turangan, 2014). Faktor Keamanan (FS) lereng tanah dapat dihitung dengan berbagai metode. FS dapat dihitung dengan metoda sayatan (slice method). Dalam mengantisipasi lereng longsor, sebaiknya nilai FS yang diambil adalah nilai FS yang terkecil, dengan demikian antisipasi akan diupayakan maksimal.

Bowles (1991, dalam Zakaria 2016) mengklasifikasikan nilai faktor keamanan menjadi tiga tingkatan sebagai berikut :

Tabel 2. Klasifikasi longsor Bowles 1991

\begin{tabular}{|l|l|l|}
\hline $\begin{array}{l}\text { Nilai Faktor } \\
\text { keamanan }\end{array}$ & Keterangan & $\begin{array}{l}\text { Kelas } \\
\text { lereng }\end{array}$ \\
\hline FS $<1.07$ & $\begin{array}{l}\text { Longsor sering } \\
\text { terjadi }\end{array}$ & Labil \\
\hline $\begin{array}{l}1.07<\text { FS }< \\
1.25\end{array}$ & $\begin{array}{l}\text { Longsor pernah } \\
\text { terjadi }\end{array}$ & Kritis \\
\hline FS $>1.25$ & $\begin{array}{l}\text { Longsor jarang } \\
\text { terjadi }\end{array}$ & Stabil \\
\hline
\end{tabular}

Analisis Angka Aktivitas Tanah lempung Peristiwa kembang susut pada lempung merupakan aktivitas yang menandakan adanya perubahan volume yang berhubungan dengan kadar air. Berdasarkan penentuan Plastic Index (PI) dari pengujian batas atterberg, dan presentase lempung yang didapat dari analisis besar butir, kedua parameter tersebut dibandingkan untuk mengetahui angka aktivitas mineral lempung (Skempton 1953).

$$
\text { Clay Activity }=\frac{\text { Plasticity Index }(P I)}{\text { Clay content }}
$$

Tabel 3. Angka Aktivitas lempung oleh Skempton (1953, dalam Hunt, 2007)

\begin{tabular}{|l|l|}
\hline Activity & Classification \\
\hline$<0.75$ & Inactive clays (kaolinite) \\
\hline $0.75-1.25$ & Normal clays (illite) \\
\hline$>1.25$ & $\begin{array}{l}\text { Active clays } \\
\text { (montmorilonite) }\end{array}$ \\
\hline
\end{tabular}

\section{Skema Penelitian}

Penelitian diawali dengan pemetaan geologi teknik untuk mengetahui sebaran tanah pada daerah penelitian juga batuan penyusun, kemudian pemetaan geologi teknik dilakukan bersamaan dengan pengambilan sampel tanah dan batuan dengan metode test pit, handauger, dan bor SPT. Setelah pemetaan geologi teknik dilakukan, sampel dibawa ke laboratorium untuk dilakukan uji sifat fisik dan sifat mekanik. Dari hasil analisis laboratorium didapatkan variabel-variabel yang digunakan dalam melakukan analisis kestabilan lereng dan angka aktivitas tanah lempung. 


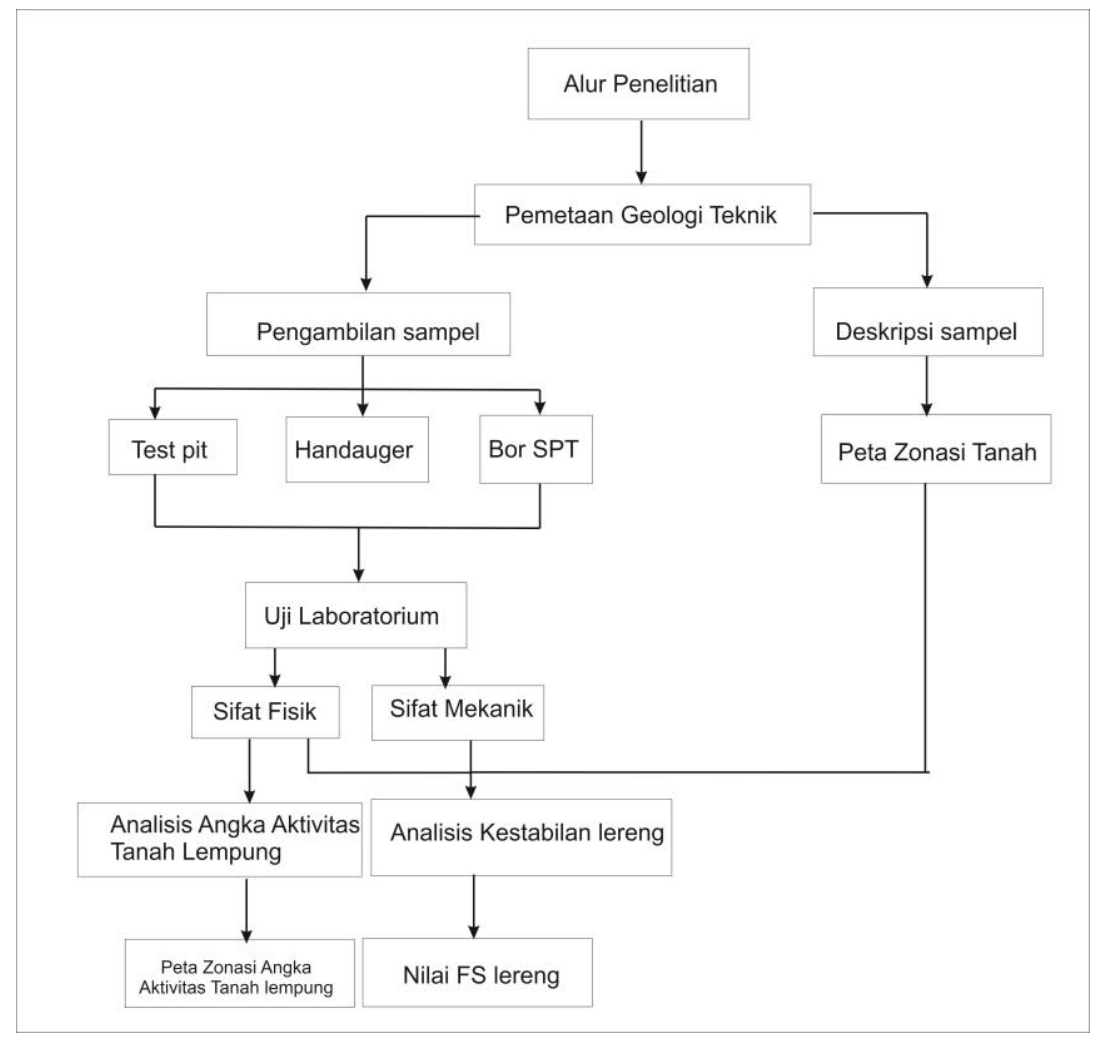

Gambar 2. Tahapan skema penelitian

HASIL DAN ANALISIS

\section{Kestabilan Lereng Daerah Penelitian}

Berdasarkan peta topografi berskala 1:8000

dan interval kontur 4 meter, kemudian dilakukan penarikan penampang sebagai acuan geometri lereng yang akan dilakukan analisis kestabilan lerengnya. Penarikan penampang yang dilakukan didasari penarikan dari puncak lereng hingga kaki lereng.

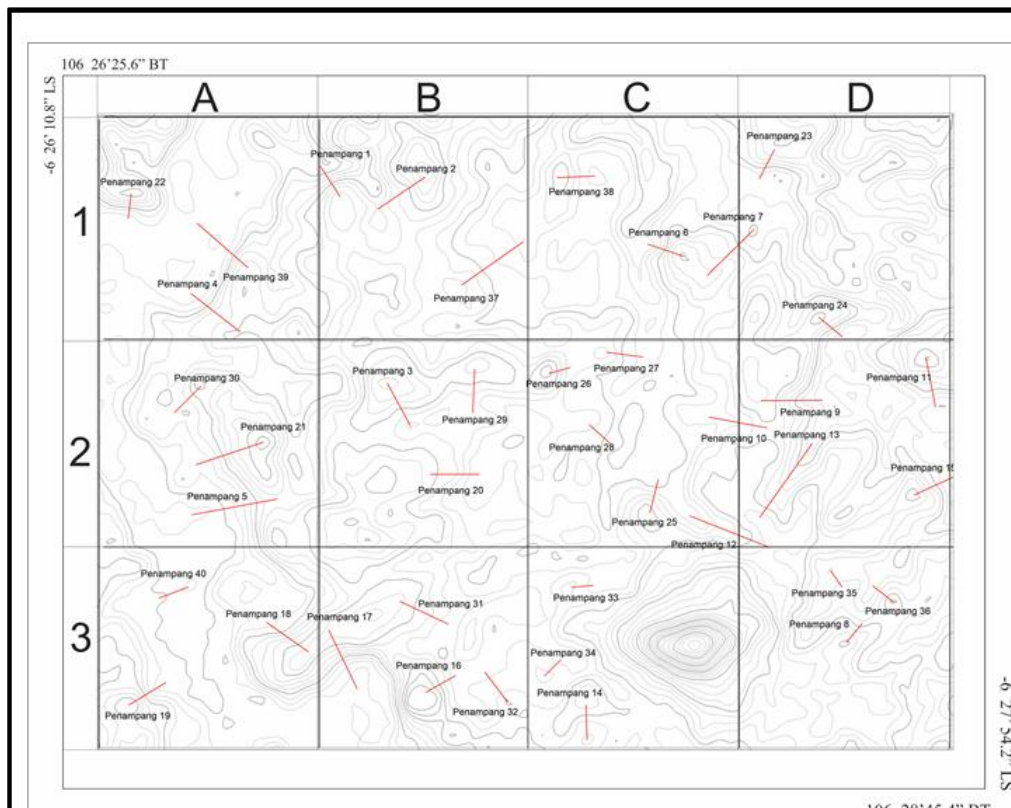

PETA PROFIL

LERENG

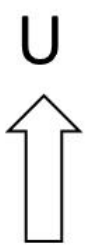

Skala 1:8000

Gambar 3. Peta profil lereng daerah penelitian

Berdasarkan analisis laboratorium yang telah dilakukan, didapat variabel bobot isi, kohesi, dan sudut geser dalam material yang sudah dirata-ratakan dengan rincian sebagai berikut: 
Tabel 4. Variabel analisis kestabilan lereng

\begin{tabular}{|c|c|c|c|}
\hline Lapisan & $\begin{array}{l}\text { Bobot isi } \\
\left(\mathbf{k N} / \mathbf{m}^{3}\right)\end{array}$ & $\begin{array}{l}\text { Kohesi } \\
\left(\mathrm{kN} / \mathrm{m}^{2}\right)\end{array}$ & $\begin{array}{l}\text { Sudut Geser } \\
\text { Dalam } \\
\left({ }^{\circ}\right)\end{array}$ \\
\hline Tanah (MH) & 15.630 & 9.430 & 4.912 \\
\hline Tanah $(\mathrm{CH})$ & 15.780 & 13.682 & 3.879 \\
\hline Batulanau & 19.875 & 217 & 21.65 \\
\hline Batupasir & 19 & 123.7 & 23.69 \\
\hline Batulempung & 18.8 & 168 & 21.14 \\
\hline
\end{tabular}

Dalam melakukan simulasi analisis kestabilan lereng menggunakan perangkat lunak SLIDE, kondisi yang diterapkan adalah kondisi material yang dipengaruhi muka air tanah dan faktor getaran, dimana muka air tanah yang diterapkan merujuk kepada Peta Isofreatik yang dibuat oleh laboratorium Hidrogeologi Unpad (2016) dan faktor getaran yang diterapkan adalah $0.15 \mathrm{G}$ (Gal) mengacu pada peta Kawasan Rawan Bencana Jawa Bagian Barat yang dibuat oleh PVMBG (2008). Kondisi lereng yang akan dianalisis dipisahkan sesuai klasifikasi kemiringan lereng van Zuidam (1985) untuk mempermudah tahap analisis berdasarkan kelas sudut lereng. Dari analisis yang telah dilakukan didapat hasil sebagai berikut:

Tabel 5. Hasil analisis kestabilan lereng

\begin{tabular}{|l|l|l|l|}
\hline Kelas & Basic & Static & Pseudostatic \\
\hline Datar & $8.053-30.15$ & $7.61-28.52$ & $1.617-3.2$ \\
\hline Sangat Landai & $3.564-9.24$ & $3.31-8.73$ & $1.094-2.08$ \\
\hline Landai & $2.063-4.9$ & $1.81-4.58$ & $0.932-1.83$ \\
\hline Agak Curam & $1.35-3.262$ & $1.206-3.09$ & $0.76-1.53$ \\
\hline
\end{tabular}

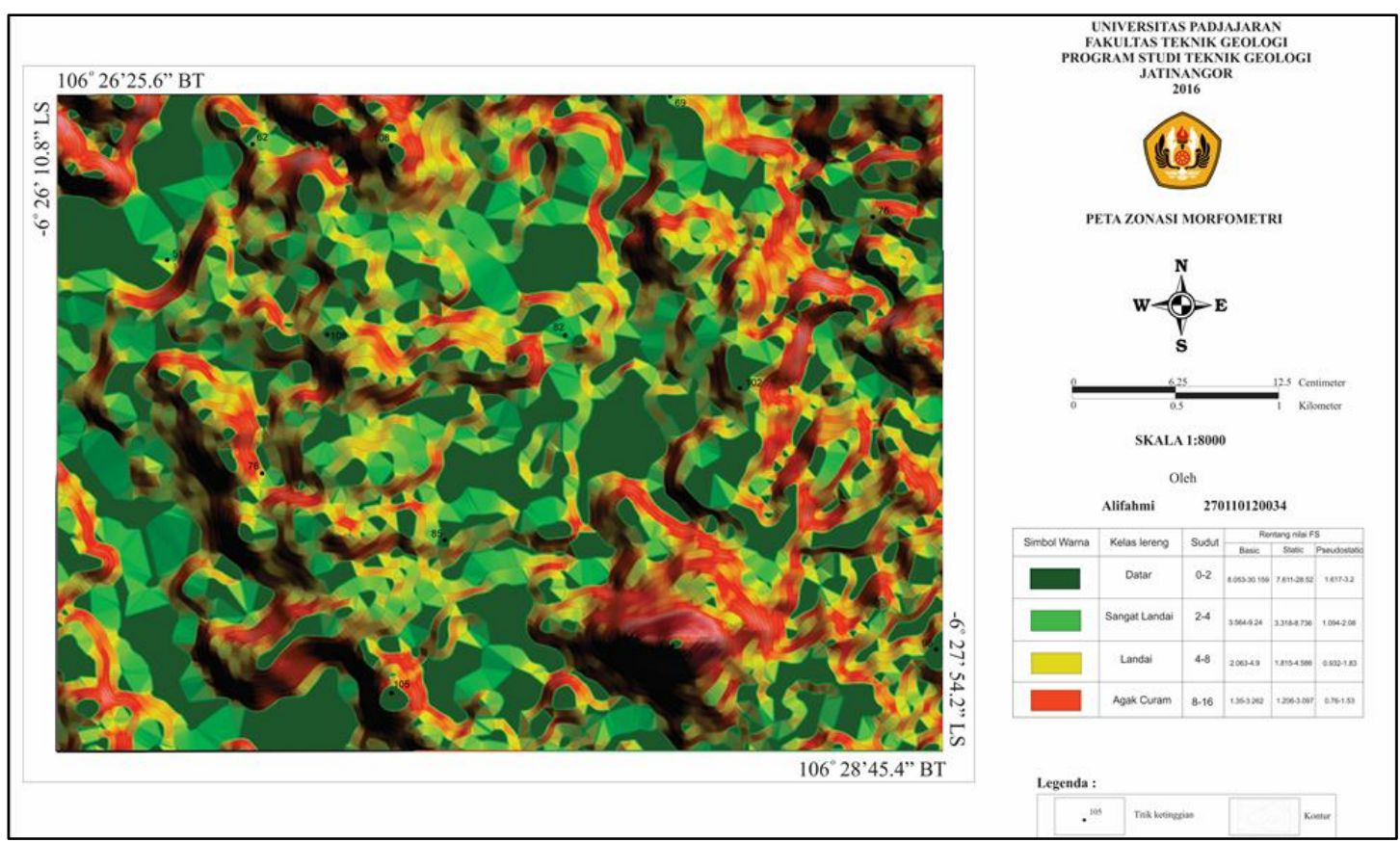

Gambar 3. Peta zonasi morfometri daerah penelitian beserta nilai FS pada tiap kelas lereng 
Dari segi kemiringan lereng daerah penelitian memiliki presentase kelas lereng datar 35\%, lereng sangat landai 35\%, lereng landai $20 \%$ dan lereng agak curam 10\%. Daerah penelitian didominasi oleh lereng datar dan landai dan memiliki nilai FS yang stabil (>1.25) hanya dibeberapa tempat memiliki nilai FS yang kritis dan labil pada kondisi static dan pseudostatic.

\section{Angka Aktivitas Tanah Lempung}

Berdasarkan hasil pengujian indeks plastisitas dan analisis butir pada sampel tanah, dilakukan analisis angka aktivitas lempung dengan membandingkan kedua variabel tersebut dan didapatkan hasil sebagai berikut:

Tabel 6. Angka aktivitas tanah lempung sampel handauger

\begin{tabular}{|l|l|l|l|l|}
\hline Bor & PI & \%Clay & $\begin{array}{l}\text { Clay } \\
\text { Activity }\end{array}$ & Jenis clay \\
\hline HA 1 & 67.38 & 86.42 & 0.78 & illite \\
\hline HA2 & 54.29 & 83.08 & 0.65 & kaolinite \\
\hline HA 3 & 32.50 & 55.82 & 0.58 & kaolinite \\
\hline HA 4 & 59.20 & 88.42 & 0.67 & kaolinite \\
\hline HA 5 & 67.96 & 92.46 & 0.74 & kaolinite \\
\hline HA 6 & 48.60 & 67.88 & 0.72 & kaolinite \\
\hline HA 7 & 53.15 & 64.76 & 0.82 & illite \\
\hline HA 8 & 49.12 & 82.84 & 0.59 & kaolinite \\
\hline HA 9 & 69.69 & 96.22 & 0.72 & kaolinite \\
\hline
\end{tabular}

Tabel 7. Angka aktivitas tanah lempung sampel test pit

\begin{tabular}{|l|l|l|l|l|}
\hline Bor & PI & \%Clay & $\begin{array}{l}\text { Clay } \\
\text { Activity }\end{array}$ & Jenis Clay \\
\hline TP1 & 73.28 & 40.19 & 1.82 & monmorilonit \\
\hline TP2 & 88.10 & 51.53 & 1.71 & monmorilonit \\
\hline TP3 & 89.82 & 67.95 & 1.32 & monmorilonit \\
\hline TP4 & 81.58 & 60.45 & 1.35 & monmorilonit \\
\hline TP5 & 94.18 & 91.95 & 1.02 & illite \\
\hline TP6 & 80.54 & 75.82 & 1.06 & illite \\
\hline TP7 & 68.46 & 23.20 & 2.95 & monmorilonit \\
\hline TP8 & 88.84 & 86.85 & 1.02 & illite \\
\hline TP9 & 94.44 & 76.19 & 1.24 & monmorilonit \\
\hline TP10 & 77.22 & 35.01 & 2.21 & monmorilonit \\
\hline TP11 & 91.80 & 76.08 & 1.21 & illite \\
\hline TP12 & 91.34 & 80.27 & 1.14 & illite \\
\hline TP13 & 92.88 & 69.93 & 1.33 & monmorilonit \\
\hline TP14 & 77.80 & 38.58 & 2.02 & monmorilonit \\
\hline TP15 & 85.44 & 69.94 & 1.22 & illite \\
\hline TP16 & 87.76 & 73.46 & 1.19 & illite \\
\hline TP17 & 88.60 & 43.11 & 2.06 & monmorilonit \\
\hline TP18 & 91.78 & 83.62 & 1.10 & illite \\
\hline TP19 & 76.18 & 46.44 & 1.64 & monmorilonit \\
\hline TP20 & 76.04 & 50.71 & 1.50 & monmorilonit \\
\hline
\end{tabular}

Dari perhitungan tersebut didapatkan angka aktivitas lempung untuk tanah pada kedalaman 2-4 meter yang diambil menggunakan metode handauger memiliki nilai angka aktivitas lempung rendah hingga normal, (sedangkan angka aktivitas lempung untuk tanah pada kedalaman 0.5-1 meter yang diambil menggunakan metode test pit memiliki nilai angka aktivitas lempung normal hingga aktif. 


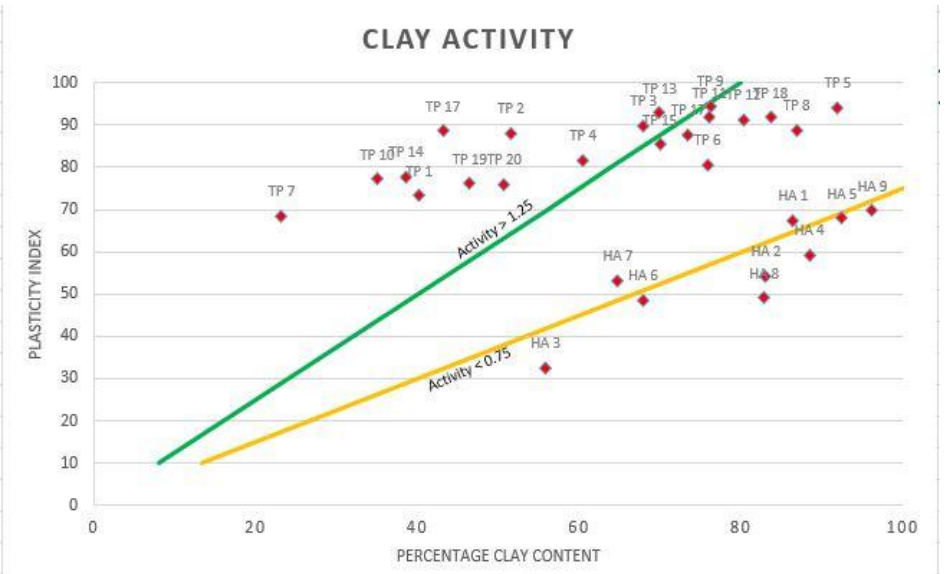

Gambar 3. Grafik indeks plastisitas terhadap kandungan lempung

Perbedaan nilai tersebut dapat terjadi karena sifat mineral lempung yang impermeable, sehingga pada kondisi hujan atau basah, air yang mengenai tanah akan mempengaruhi lapisan tanah terluar atau paling atas, tetapi karena mineral lempung bersifat impermeable menyebabkan air tertahan untuk masuk kedalam tanah pada bagian bawah, sehingga menyebabkan pengaruh air terhadap mineral lempung dominan terjadi pada tanah bagian atas dibandingkan tanah bagian bawah. Hal tersebut menyebabkan tanah pada bagian atas memiliki angka aktivitas yang lebih tinggi dibandingkan tanah bagian bawah.

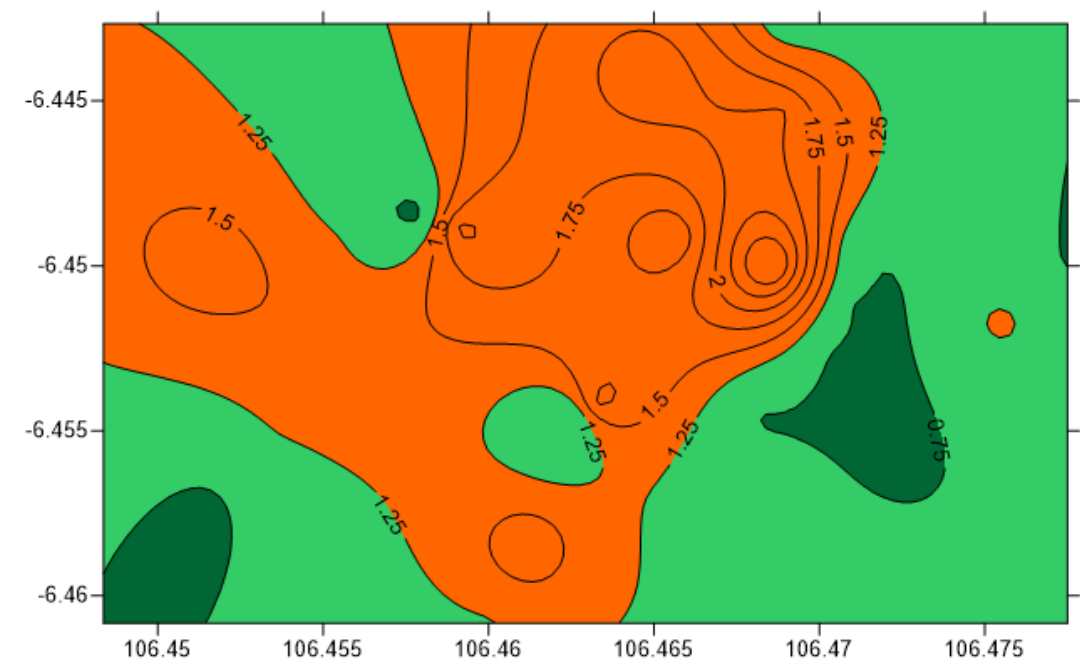

Gambar 4. Peta sebaran angka aktivitas mineral lempung

\section{KESIMPULAN}

Meskipun daerah penelitian di dominasi oleh kelas lereng yang relatif datar, tetapi daerah penelitian yang termasuk kedalam formasi Bojongmanik secara Geologi memiliki jenis tanah pelapukan yang berasal dari batulempung (Gatot M. dkk, 1992). Sehingga ada kecenderungan untuk tanah memiliki sifat mengembang dan menyusut seperti yang dimiliki oleh mineral lempung. Bagian tengah daerah penelitian yang didominasi oleh kelas lereng datar justru memiliki zonasi angka aktivitas tanah lempung yang tinggi ( $>$ 1.25) sehingga daerah tersebut tetap harus diwaspadai terutama saat curah hujan tinggi.

\section{DAFTAR PUSTAKA}

Dearman, W.R, 1991. Engineering Geological Mapping, Butterworth-Heinenmann Ltd., $387 \mathrm{~h}$.

Zakaria, Zufialdi. 2016. Beberapa Model Penelitian Kestabilan Lereng untuk Mahasiswa Program Sarjana, SEMNAS FTG UNPAD ISSN : 2407-4314 Vol.3.

Zakaria, Zufialdi. 2010. Model Starlet, suatu Usulan untuk Mitigasi Bencana Longsor dengan Pendekatan Genetika Wilayah (Studi Kasus: Longsoran Citatah, Padalarang, Jawa), Jurnal Geologi Indonesia, Vol. 5 No.2 Juni 2010: 93-112 Hunt, Roy E. 2007. Characteristic of Geologic Materials and Formations A Field Guide 
Bulletin of Scientific Contribution, Volume 14, Nomor 3, Desember 2016 : 269 - 276

for Geotechnical Engineer. Taylor \& Francis Group: New York

Skempton, Alec W. 1953. The Coloidal Activity of Clays. $3^{\text {rd }}$ International Conference Soil Mech found Eng. Switzerland, vol. 1.

Lestari, I Gusti A.I. 2014. Karakteristik Tanah Lempung Ekspansif (Studi Kasus di Desa Tanah Awu, Lombok Tengah). GaneC Swara vol.8 No.2.

Rusmana, E., Suwitodirjo, K., Suharsono. 1991. Peta Geologi Bersistem, Jawa Lembar : Serang. Pusat Penelitian dan Pengembangan Geologi, Bandung.

Sudrajat, G.M., dan Sudibjo. 1992. Peta Geologi Teknik Bersistem, Jawa Lembar : Serang. Direktorat Geologi Tata Lingkungan. Bandung. 